Brit. J. industr. Med., 1953, 10, 111.

\title{
A PILOT INVESTIGATION INTO THE OCCURRENCE OF PNEUMOCONIOSIS IN LARGE POWER STATIONS IN SOUTH WALES
}

\author{
BY \\ IDRIS DAVIES \\ From the South Wales Division of the British Electricity Authority
}

(RECEIVED FOR PUBLICATION MARCH 21, 1952)

In the large electricity generating stations where coal is used both the coal and the resultant ash are enclosed and handled mechanically. Nevertheless, considerable quantities of dust are found on the tops of machinery, on ledges, and in crevices, and the workmen in some parts of the station get their faces and clothes covered with dust. As there have been, as far as it is known, no previous studies of the possibility of pneumoconiosis arising from exposure to dust in electricity generating stations, it was decided in the first instance to examine radiologically a group of men employed in these stations in South Wales. South Wales was chosen because the mobile $x$-ray unit of the M.R.C. Pneumoconiosis Research Unit, which could ensure films of a high technical standard, was close at hand, and pneumoconiosis was more likely to occur in stations handling coal from the South Wales fields where miners show a higher incidence of dust disease than in any other British coal field. It was also supposed that in this region, where the association of pneumoconiosis with coal dust is so well known, the cooperation from the men would be good. There was, however, one disadvantage which was not overlooked. Many of the men employed in power stations had also worked in coal mines for varying periods. If pneumoconiosis were found in these men it would be difficult to know which occupation had caused it.

Four large stations were selected for the investigation because they were conveniently situated and were representative of the different conditions in this region, for example, in the type of coal used and the methods of stoking boilers. There appeared to be several sources of exposure to dust : from coal tipping in the bunker houses, and from the pulverizing mills and large pipes conveying the pulverized fuel, from the ash from boilers and precipitators, although much of the ash is carried away by water; from the maintenance and repair of mechanical and electrical equipment by fitters and their mates, when a large amount of settled dust is disturbed, particularly in dismantling equipment; and from the maintenance and cleaning of boilers and precipitators.

It was not possible to separate the men employed on these jobs into occupational groups as most of the men are constantly changing their type of work. Bricklayers and laggers who are continually employed on this work, can, however, be considered separately. The bricklayers go inside boilers to chip away worn and broken silica bricks. During this work the boilers are open and a gentle air stream is passed through them but the men are exposed to considerable quantities of siliceous dust. The laggers strip asbestos off steam pipes being repaired, and are exposed to clouds of fine asbestos dust.

\section{Method of Investigation}

Approximately $50 \%$ of the men at risk volunteered for examination. Some refused to be examined, others who were on shift work were missed, and in two stations an influenza epidemic caused many to be absent. The date of birth and the length of past and present occupations within and outside the power stations were recorded. Large films were taken, and were read on two separate occasions without reference to the industrial histories by Dr. A. L. Cochrane and myself. They were classified by the method described by Cochrane, Davies, and Fletcher (1951).

\section{Results}

Five hundred and seventy-two men were examined. Table 1 shows the numbers examined and at risk in each age group according to the time they had worked in power stations. 
TABLE 1

ANALYSIS OF THE TOTAL NUMBER OF MEN AT HAZARD ACCORDING TO AGE AND YEARS SPENT IN THE POWER STATIONS

\begin{tabular}{|c|c|c|c|c|c|c|c|c|c|c|c|c|c|c|c|c|}
\hline \multirow{3}{*}{\multicolumn{2}{|c|}{$\begin{array}{c}\text { Age } \\
\text { Groups } \\
\text { (years) }\end{array}$}} & \multicolumn{15}{|c|}{ Years Worked in the Power Stations } \\
\hline & & \multicolumn{3}{|c|}{ Under 10} & \multicolumn{3}{|c|}{$10-19$} & \multicolumn{3}{|c|}{$20-29$} & \multicolumn{3}{|c|}{30 and over } & \multicolumn{3}{|c|}{ Total } \\
\hline & & Total & $\begin{array}{c}\text { No. } \\
X \text {-rayed }\end{array}$ & $\%$ & Total & $\begin{array}{c}\text { No. } \\
X \text {-rayed }\end{array}$ & $\%$ & Total & $\begin{array}{c}\text { No. } \\
X \text {-rayed }\end{array}$ & $\%$ & Total & $\begin{array}{c}\text { No. } \\
X \text {-rayed }\end{array}$ & $\%$ & Total & $\begin{array}{c}\text { No. } \\
X \text {-rayed }\end{array}$ & $\%$ \\
\hline$\overline{16-29}$ & . & 200 & 95 & $47 \cdot 5$ & - & 一 & - & 一 & 一 & 一 & - & - & - & 200 & 95 & $47 \cdot 5$ \\
\hline $30-39$ & . & 204 & 124 & 60 & 30 & 15 & 50 & - & - & - & - & - & - & 234 & 139 & 59 \\
\hline 50 anc & & 197 & 69 & 35 & 133 & 66 & 50 & 18 & 13 & 72 & 48 & 19 & 40 & 396 & 167 & 42 \\
\hline & . & 811 & 408 & 50 & 250 & 126 & 50 & 23 & 17 & 74 & 54 & 21 & 39 & 1,138 & 572 & 50 \\
\hline
\end{tabular}

Seventy-one per cent. of the men at risk had worked for less than 10 years in power stations and $93 \%$ for less than 20 years. Half of the men who were 50 years old or more had worked in these stations for less than 10 years. Thus the length of the working period has not the usual relationship with age because the electricity generating industry has roughly doubled its output every seven years since 1932, and in South Wales many men enter this industry from the mines and the steel industry as the work is less arduous. The sample is, unfortunately, unsatisfactory from the statistical point of view because it is a volunteer sample with all its inherent weaknesses.

Incidence of Pneumoconiosis.-There were 57 men with pneumoconiosis, and every one of them had worked underground.

There were 407 men who had never worked underground, and it will be seen from Table 2 that

TABLE 2

ANALYSIS BY YEARS OF EXPOSURE OF MEN WORKING IN POWER STATIONS WHO HAD NEVER WORKED UNDERGROUND

\begin{tabular}{|c|c|c|c|c|c|}
\hline \multicolumn{4}{|c|}{$\begin{array}{l}\text { Years in Power } \\
\text { Stations }\end{array}$} & \multirow{2}{*}{ No. of Men } & \multirow[t]{2}{*}{$\begin{array}{c}\text { No. with } \\
\text { Pneumoconiosis }\end{array}$} \\
\hline Under 10 & . & . & . & & \\
\hline $10-19 \ldots$ & $\cdots$ & . & . & 86 & \multirow{2}{*}{ Nil } \\
\hline $20-29 \ldots$ & $\cdots$ & $\cdots$ & $\cdots$ & 15 & \\
\hline 30 and over & . & $\cdots$ & . & 16 & \\
\hline Total & . & $\ldots$ & .. & 407 & \\
\hline
\end{tabular}

117 had worked in power stations for more than 10 years, yet none showed any radiological evidence of pneumoconiosis. In this group there were seven bricklayers and three mates; one bricklayer had worked for 11 years, the remainder for seven years or less. There were also four laggers and three mates. One lagger had worked for 10 years and the remainder for less than six years. There were 165 who had worked both underground and in power stations and 57 were found to have definite radiological evidence of pneumoconiosis. In Table 3 it is shown that the severity of pneumoconiosis is related to the period worked underground. Of the 13 men with complicated pneumoconiosis only one had worked for less than 20 years in a coal mine.

Other Diseases.-Fourteen men had radiological evidence of pulmonary tuberculosis other than healed primary lesions ; of these lesions three were thought to be active, and the men were referred to the chest clinic.

\section{Discussion}

Since the conditions in the power stations were apparently dusty, it was rather surprising to find no evidence of pneumoconiosis among the men examined who had not worked underground but it must be remembered that only half the workers were examined. While there is no reason to suppose that there would be pneumoconiosis in those who did not volunteer, this possibility cannot be excluded. However, Cochrane (1951) found in a colliery survey that there was less pneumoconiosis in the last volunteers examined than in the first volunteers, so that it is unlikely.

Similar conditions found in screening and trimming coal and in processing it to make patent fuels are known to produce pneumoconiosis (Gough, 1940; Hart and Aslett, 1942). Ash-dust from coke fires in gas works in association with sulphur dioxide is thought by Dunner, Hardy, and Bagnall (1949) to cause pneumoconiosis, and it has also been found in boiler-scalers cleaning the flue dust in the fire tubes arising from coal and other fuels (Harding and Massie, 1951).

The reasons for finding no evidence of pneumoconiosis in the volunteers examined is probably chiefly the high rate of ventilation in power stations 
TABLE 3

ANALYSIS OF MEN WHO HAD WORKED IN BOTH COAL MINES AND POWER STATIONS BY YEARS WORKED UNDERGROUND AND AMOUNT AND SEVERITY OF PNEUMOCONIOSIS

\begin{tabular}{|c|c|c|c|c|c|c|c|c|c|}
\hline \multirow{2}{*}{\multicolumn{3}{|c|}{$\begin{array}{l}\text { Years Worked } \\
\text { Underground }\end{array}$}} & \multirow[b]{2}{*}{$\begin{array}{c}\text { Total No. } \\
\text { of Men }\end{array}$} & \multicolumn{4}{|c|}{ No. with Pneumoconiosis } & \multirow{2}{*}{$\begin{array}{c}\text { Total } \\
\text { Pneumoconiosis } \\
\text { Cases }\end{array}$} & \multirow{2}{*}{$\begin{array}{c}\text { Percentage } \\
\begin{array}{c}\text { Pneumoconiosis } \\
\text { Cases }\end{array}\end{array}$} \\
\hline & & & & $\begin{array}{c}\text { Category } \\
1\end{array}$ & $\begin{array}{c}\text { Category } \\
2\end{array}$ & Category & $\begin{array}{l}\text { Complicated } \\
\text { Pneumo- } \\
\text { coniosis }\end{array}$ & & \\
\hline Under 10 & . & . & 68 & 2 & 1 & - & - & 3 & $4 \cdot 4$ \\
\hline $10-19$ & $\cdots$ & . & 51 & 10 & 7 & 1 & 1 & 19 & $37 \cdot 2$ \\
\hline $20-29$ & $\cdots$ & $\ldots$ & 35 & 5 & 8 & 6 & 6 & 25 & $71 \cdot 4$ \\
\hline \multicolumn{2}{|l|}{30 and over } & $\cdots$ & 11 & 3 & 1 & - & 6 & 10 & $90 \cdot 9$ \\
\hline \multicolumn{2}{|c|}{ Total $\ldots$} & $\ldots$ & 165 & 20 & 17 & 7 & 13 & 57 & 10 \\
\hline
\end{tabular}

provided by forced draught fans supplying air to the boilers. The intake ducts of these fans are at the top of the building and take in air at the rate of $300,000-500,000 \mathrm{cu}$. ft. per min. This produces an enormous rate of air change at every working level inside the station and should keep the concentration of atmospheric dust at a low level. There is little or no air movement immediately above solid objects such as pipes, machinery, and ledges and it is here that the dust collects, but it is doubtful if the particle size of settled dust is small enough to produce disease (Hatch, 1951). Further, the majority of workmen seen had not spent many years working in power stations and some, such as boiler cleaners and maintenance men, do this work only in the summer months. A general inspection of bricklaying and lagging suggests that there is a risk of pneumoconiosis here but probably neither the number of men examined nor the lengths of exposure were sufficient to show it.

At the worst the risk of pneumoconiosis in power stations cannot be very high, but another $x$-ray survey of the same men at a later date would give more conclusive evidence.

\section{Summary}

Five hundred and seventy-two men out of 1,138 from four large power stations were radiologically examined using large films. Fifty-seven men were found to be suffering from pneumoconiosis and every one of them had worked underground in coal mines. No case of pneumoconiosis was found in the 407 men who had not worked underground. And of these 117 had worked for more than 10 years and 31 for more than 20 years in power stations. The reasons for this are discussed. It is thought that a hazard exists, especially to bricklayers and laggers and their mates, and also to boiler cleaners and maintenance men, but the exposure has probably been too short to produce pneumoconiosis. The very high rate of ventilation may be responsible for preventing disease in most of the workers in the power stations.

I wish to thank Dr. Peter Pringle, the Chief Medical Officer to the British Electricity Authority, for his advice and assistance and for permission to publish the results; Mr. H. V. Pugh, the Divisional Controller, Miss E. N. S. Morgan, the Nursing Superintendent, and other members of the staff of the South Wales Division for their cooperation and assistance. I am also indebted to my colleagues in the Pneumoconiosis Research Unit for advice and assistance, and to members of the mobile $x$-ray unit for their enthusiasm and the high technical standard they maintained.

\section{REFERENCES}

Cochrane, A. L. (1951). The Application of Scientific Methods to Industrial and Service Medicine, p. 97. H.M.S.O. London. Davies, I., and Fletcher, C. M. (1951). British Journal of Industrial Medicine, 8, 244.

Dunner, L., Hardy, R., and Bagnall, D. J. T. (1949). Lancet, 2, 1214 Gough, J. (1940). J., Path. Bact., 51, 277.

Harding, H. E., and Massie, A. P. (1951). British Journal of Industrial Medicine, 8, 256.

Hart, P. D'Arcy, and Aslett, E. A. (1942). Spec. Rep. Ser. med. Res. Coun. Lond., No. 243.

Hatch, T. F. (1951). Third International Conference on Pneumoconiosis, Sydney, 1950. 